\title{
Sistem Pengolah Musik Sebagai Kontrol Gerak Robot Humanoid
}

\author{
Irmawan Anang Maulana ${ }^{1}$, Nuryono Satya Widodo ${ }^{2}$ \\ ${ }^{1}$ Mahasiswa Program Studi Teknik Elektro, Universitas Ahmad Dahlan, Indonesia \\ ${ }^{2}$ Dosen Program Studi Teknik Elektro, Universitas Ahmad Dahlan, Indonesia
}

\section{INFORMASI ARTIKEL \\ Riwayat Artikel: \\ Dikirimkan 31 Juli 2019, \\ Direvisi 16 Agustus 2019, \\ Diterima 01 September 2019.}

\section{Kata Kunci:}

Robot Humanoid, IC MSGEQ7,

Pengolah Musik,

Isyarat Gerak,

FFT (Fast Fourier Transform).

\section{Penulis Korespondensi:}

Irmawan Anang Maulana, Program Studi Teknik Elektro, Universitas Ahmad Dahlan, Kampus 4 UAD, Jln. Ring Road Selatan, Tamanan, Banguntapan, D.I. Yogyakarta, Indonesia.

Surel: iamirmawan@gmail.com

\begin{abstract}
ABSTRAK
Pada Kontes Robot Seni Tari Indonesia (KRSTI), mengharuskan peserta untuk dapat membuat robot yang dapat menari secara otomatis dengan diiringi alunan musik. Tujuan penelitian ini adalah membuat robot humanoid yang dapat menari ketika musik pengiring diputar dan berhenti ketika musik berhenti. Penelitian ini menggunakan IC MSGEQ7 sebagai pengolah musik karena IC ini dapat membaca nilai frekuensi musik secara detail sebanyak tujuh frekuensi yaitu frekuensi $63 \mathrm{~Hz} ; 16 \mathrm{~Hz} ; 400 \mathrm{~Hz}, 1 \mathrm{kHz} ; 2,5 \mathrm{kHz} ; 6,25 \mathrm{kHz}$; dan $16 \mathrm{kHz}$. Ketujuh frekuensi tersebut dijadikan acuan sebagai isyarat robot untuk bergerak atau berhenti. Penentuan frekuensi sebagai isyarat gerak didapat melalui sampling musik Tari Remo menggunakan perangkat lunak Matlab dengan metode FFT (Fast Fourier Transform). Isyarat gerak tersebut dikirimkan ke sistem robot melalui Modul Bluetooth HC-05. Jika sistem robot mendapat isyarat untuk bergerak maka robot akan menggerakkan servo penggerak menjadi gerakan yang serasi. Hasil yang didapat dari pengujian adalah dapat diketahui frekuensi yang sering muncul pada musik tari remo yaitu pada frekuensi $0-4000 \mathrm{~Hz}$. Setelah frekuensi diketahui, implementasi pada robot memperoleh hasil robot dapat menari ketika musik diputar dan robot dapat berhenti ketika musik dihentikan.
\end{abstract}

At the Indonesian Dance Robot Contest (KRSTI), it requires participants to be able to make robots that can dance automatically accompanied by music. The purpose of this study is to create a humanoid robot that can dance when the accompaniment music is playing and stop when the music stops. This study uses IC MSGEQ7 as a music processor because this IC can read music frequency values in detail as many as seven frequencies namely $63 \mathrm{~Hz}$ frequency; $16 \mathrm{~Hz} ; 400 \mathrm{~Hz}, 1 \mathrm{kHz} ; 2.5 \mathrm{kHz} ; 6.25 \mathrm{kHz} ;$ and $16 \mathrm{kHz}$. The seven frequencies are used as a reference as a robot signal to move or stop. The determination of the frequency as a gesture is obtained through the sampling of Remo Dance music using Matlab software with the FFT (Fast Fourier Transform) method. These motion signals are sent to the robot system via the Bluetooth Module HC-05. If the robot system gets a signal to move, the robot will move the servo drive into a matching movement. The results obtained from testing are the frequency that often appears in Remo dance music, namely the frequency $0-4000 \mathrm{~Hz}$. After the frequency is known, the implementation of the robot obtains the results that the robot can dance when the music is playing and the robot can stop when the music is stopped.

This work is licensed under a Creative Commons Attribution-Share Alike 4.0

\section{Sitasi Dokumen ini:}

I. A. Maulana and N. S. Widodo, "Sistem Pengolah Musik Sebagai Kontrol Gerak Robot Humanoid," Buletin Ilmiah Sarjana Teknik Elektro, vol. 1, no. 2, pp. 46--55, 2019. DOI: 10.12928/biste.v1i2.915

\section{PENDAHULUAN}

Kontes Robot Seni Tari Indonesia (KRSTI) merupakan ajang kompetisi robot yang mengandung unsur seni budaya dan telah diselenggarakan setiap tahun terhitung sejak tahun 2009 hingga sekarang (dahulu disebut KRSI). Dalam penyelenggaraannya KRSTI setiap tahun mengambil tema yang berbeda-beda, pada tahun 2018 tema yang diangkat adalah Tari Remo [1]. 
Dalam pelaksanaan kontes robot seni tari, robot akan ditempatkan di arena dalam kondisi siap untuk menunggu musik dari juri dimulai. Dimulainya musik dari juri menandakan pertandingan dimulai maka robot akan menari dengan gerakan yang sudah dibuat selama musik berjalan, dalam pelaksanaannya musik akan dihentikan sebanyak satu kali secara acak dan ketika musik berhenti robot juga harus berhenti, musik tersebut akan berhenti selama 10 detik dan akan dilanjutkan kembali hingga musik selesai.

Untuk dapat mendeteksi musik, disediakan Bluetooth audio dari panitia. Kualitas koneksi sambungan antara Bluetooth audio robot dengan Bluetooth audio di sisi juri, tidak jarang mengalami gangguan seperti terputusnya koneksi [2]. Pada saat ini tim KRSTI UAD belum memiliki sistem pengolah musik berdasarkan frekuensi, sehingga robot tidak dapat menari ketika musik diputar. Hal tersebut sangat berpengaruh pada hasil pelaksanaan kontes robot seni tari karena memiliki poin yang cukup tinggi sebesar 10 poin dan ketika robot tidak dapat mendengar musik maka robot tidak bergerak dan robot dianggap tidak dapat menari.

Berdasarkan permasalahan di atas, penelitian ini membuat sistem pengolah musik menggunakan IC MSGEQ7 untuk memperoleh isyarat gerak robot. IC MSGEQ7 merupakan IC CMOS yang dapat membagi spectrum audio menjadi tujuh frekuensi dengan rentang nilai $63 \mathrm{~Hz} ; 16 \mathrm{~Hz} ; 400 \mathrm{~Hz} ; 1 \mathrm{kHz} ; 2,5 \mathrm{kHz} ; 6,25 \mathrm{kHz}$; dan 16kHz. Untuk dapat bekerja, perancangan modul MSGEQ7 membutuhkan beberapa komponen seperti resistor dan kapasitor untuk mengaktifkan clock internal MSGEQ7 [3]. Penentuan frekuensi sebagai isyarat, diperoleh melalui sampling musik Tari Remo menggunakan Matlab dengan metode FFT. Proses sampling ini dilakukan menggunakan laptop secara terpisah dengan robot sebagai proses untuk mendapatkan komponen penyusun frekuensi [4].

Untuk mengirim isyarat gerak yang diperoleh, dibuat sistem pengirim isyarat menggunakan modul Bluetooth HC-05. Modul Bluetooth ini kecepatan pengiriman data dapat diatur sehingga data yang dikirim akurat dan ketika koneksi Bluetooth terputus, koneksi dapat tersambung secara otomatis. Modul Bluetooth ini mempunyai jangkauan sejauh kurang lebih 10 meter dan mempunyai kecepatan pengiriman hingga 3 Mbps [5].

Dalam Tari Remo gerakan robot humanoid didapat dengan cara mengombinasikan beberapa gerakan perputaran sudut motor servo yang tersusun sesuai dengan DOF pada bagian tubuh robot humanoid [6]. Dalam pembuatan gerakan diperlukan gerakan dasar manusia. Gerakan dasar ini selanjutnya akan digunakan sebagai acuan gerakan robot humanoid yang memungkinkan untuk dilakukan [7]. Motor servo yang digunakan adalah servo Dynamixel, servo Dynamixel dapat dikontrol dengan akurasi yang baik dengan resolusi posisi mencapai 1024 steps [8].

Penelitian yang terkait dengan robot KRSTI yang telah dilakukan sebelumnya yaitu, sebagaimana dalam penelitian [9] dengan judul Pengolah Sinyal Suara Sebagai Pemicu Gerakan Robot Bioloid CM-530 Menggunakan Arduino, membuat suatu sistem untuk mengolah musik menjadi pemicu gerak robot yang diterima oleh Bluetooth Audio Receiver, pada sistem robot pertama musik yang diterima akan diolah dalam Arduino Due menggunakan algoritme FFT untuk mengetahui nilai frekuensi penyusun musik dengan perhitungan detak $260 \mathrm{~Hz}$ untuk menentukan pemicu gerak robot. Setelah sistem pertama berhasil mengolah musik maka akan dikirimkan ke sistem robot kedua melalui komunikasi serial secara wireless menggunakan Bluetooth HC-05 yang diolah dalam Arduino nano untuk dijadikan pemicu gerak robot. Ketepatan rata-rata pemicuan menggunakan metode ini untuk robot satu yaitu 33\% dan robot dua yaitu 22\% [9].

Penelitian oleh [10] dengan judul Rancang Bangun Sistem Motion Capture dan Database Motion untuk Robot Humanoid dengan Perangkat Microsoft Kinect Berbasis ROS, berfokus dalam pengembangan motion capture untuk mentransformasi gerakan lengan manusia ke lengan robot humanoid yang terdiri dari 3 DOF secara real time serta merancang database motion agar robot dapat melakukan gerakan yang telah disimpan. Motion capture yang telah dibuat memiliki batasan jangkauan kerja 0,4-4 meter dengan error rata-rata pembacaan setiap vektor skeleton sebesar $1,74 \mathrm{~cm} \mathrm{[10].}$

Berdasarkan penelitian yang telah dilakukan oleh peneliti [9] dan [10], peneliti mengembangkan kembali perangkat keras dan perangkat lunak pengolah musik menggunakan rangkaian audio analyser MSGEQ7. Penelitian ini diharapkan dapat menghasilkan sistem pengolah musik yang dapat mendeteksi musik ketika diputar atau berhenti.

\section{METODE PENELITIAN}

Penelitian ini berpusat pada pengembangan sistem pengolah musik agar dapat mendeteksi ketika musik sedang diputar atau musik dalam keadaan berhenti untuk dijadikan isyarat gerak robot, dan mengembangkan pengiriman isyarat gerak robot yang telah diperoleh ke robot melalui Bluetooth HC-05.

\subsection{Desain Sistem Pengolah Musik}

Dalam penelitian ini perancangan sistem pengolah musik dilakukan sampling musik terlebih dahulu menggunakan algoritme FFT (Fast Fourier Transform) pada MATLAB untuk mendapat frekuensi yang sesuai pada musik tari remo. Kemudian nilai frekuensi yang didapat akan diterapkan pada perangkat keras sistem pengolah musik sebagai nilai acuan untuk isyarat gerak robot. 


\subsubsection{Sampling Frekuensi Musik Tari Remo}

Algoritme FFT digunakan untuk sampling frekuensi musik tari remo. Sampling ini bertujuan untuk mencari nilai frekuensi yang paling stabil dan paling sering muncul di antara ketujuh nilai frekuensi yang dibaca IC MSGEQ7. Sampling frekuensi dilakukan menggunakan perangkat lunak MATLAB dengan memasukkan musik tari remo yang formatnya sudah diubah ke format WAV. Musik tersebut diolah menggunakan metode FFT dengan rentang nilai frekuensi $63 \mathrm{~Hz} ; 16 \mathrm{~Hz} ; 400 \mathrm{~Hz} ; 1 \mathrm{kHz} ; 2,5 \mathrm{kHz} ; 6,25 \mathrm{kHz}$; dan $16 \mathrm{kHz}$. Hasil pengolahan musik ditampilkan dalam bentuk gelombang untuk memudahkan dalam mencari nilai frekuensi yang sesuai.

Gelombang asli musik tari remo dapat dilihat pada Gambar 1 dengan sumbu x adalah nilai amplitudo dan sumbu y adalah waktu. Berdasarkan gambar tersebut terdapat berbagai nilai frekuensi pada musik tari remo dengan kerapatan yang bervariasi. Selain itu nilai amplitudo musik tari remo ada yang bernilai positif dan bernilai negatif. Dengan menggunakan hasil gambar yang masih mentah tersebut akan sulit untuk mengetahui berapa nilai frekuensi yang sering muncul. Oleh karena itu, untuk mengetahui nilai frekuensi yang sering muncul, diperlukan metode FFT (Fast Fourier Transform).

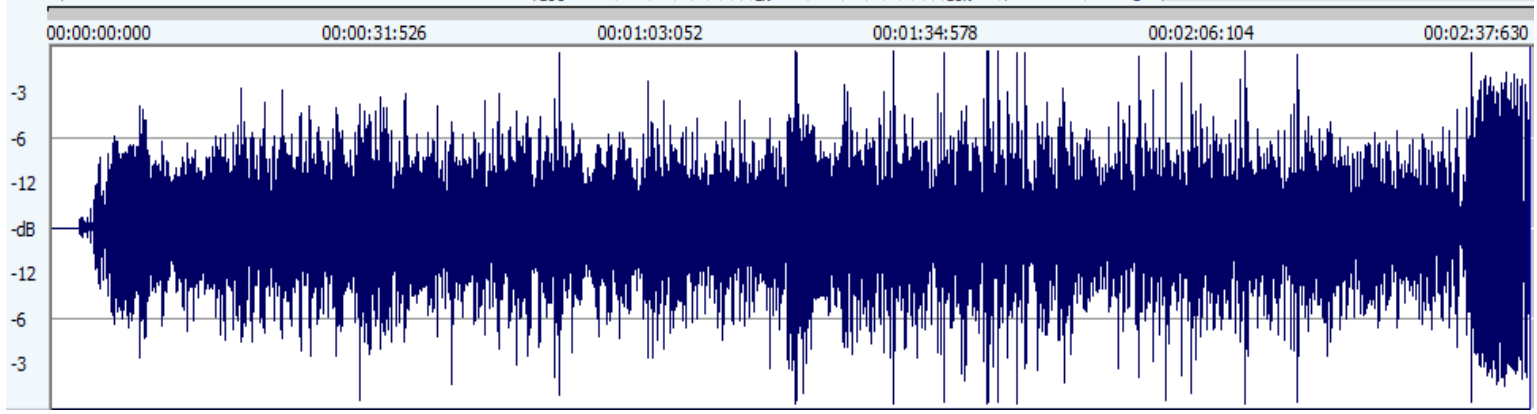

Gambar 1. Gelombang Musik Tari Remo

\subsubsection{Diagram Blok Sistem Pengolah Musik}

Diagram blok sistem pengolah musik dapat dilihat pada Gambar 2, perangkat keras sistem pengolah musik dihubungkan dengan jack audio yang disediakan oleh panitia kontes robot. Ketika IC MSGEQ7 menerima sinyal frekuensi musik dari pemutar musik, maka sinyal frekuensi akan diolah dalam mikrokontroler Arduino Pro Mikro sebagai isyarat gerak robot dengan acuan nilai frekuensi yang telah didapat pada proses sampling di MATLAB. Isyarat gerak yang telah diperoleh maka akan ditampilkan dalam LCD OLED untuk mempermudah pengamatan dan isyarat gerak akan dikirimkan ke robot melalui Bluetooth HC-05.

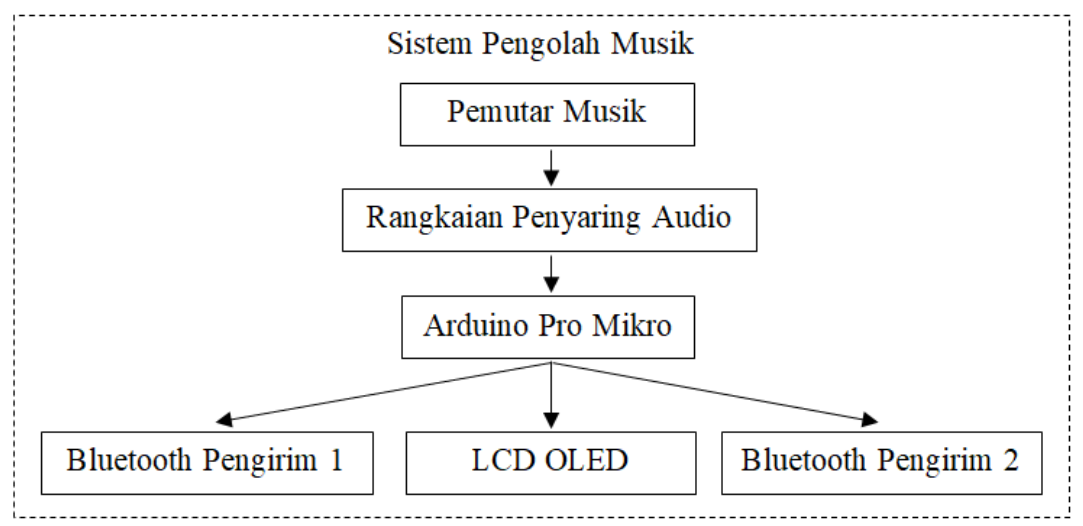

Gambar 2. Diagram Blok Sistem Pengolah Musik

\subsubsection{Diagram Alir Sistem Pengolah Musik}

Diagram alir sistem pengolah musik dapat dilihat pada Gambar 3. Ketika sistem dinyalakan maka IC MSGEQ7 akan membaca nilai frekuensi yang diterima dari jack audio juri, setelah nilai frekuensi didapat kemudian diolah pada mikrokontroler untuk diubah menjadi isyarat gerak dengan acuan nilai frekuensi hasil sampling dan kemudian dikirimkan ke robot melalui Bluetooth HC-05. Keluaran dari sistem pengolah musik berupa bilangan biner yaitu 1 untuk bergerak dan 0 untuk berhenti. 


\subsection{Desain Sistem Robot}

Perancangan robot menggunakan desain robot humanoid dengan 29 derajat kebebasan, 5 servo pada badan, 10 servo pada lengan, 2 servo kepala, dan 12 servo pada kaki.

\subsubsection{Diagram Blok Sistem Robot}

Diagram blok sistem robot dapat dilihat pada Gambar 4. Ketika sistem robot mendapat isyarat gerak dari sistem pengolah musik maka akan diproses dalam kontroler Open CM 9.04, ketika terdapat instruksi untuk robot bergerak maka Open CM 9.04 akan mengirimkan nilai-nilai servo ke penggerak robot melalui papan ekspansi Open CM 845. Kemudian nilai-nilai servo yang diterima aktuator robot akan dijadikan gerak sesuai alamat servo untuk mendapatkan gerakan yang serasi. Gerakan tari yang dibuat menggunakan nilai-nilai servo pada setiap langkah, satu langkah mewakili satu buah gerakan tari yang nantinya akan digabungkan menjadi tari remo.

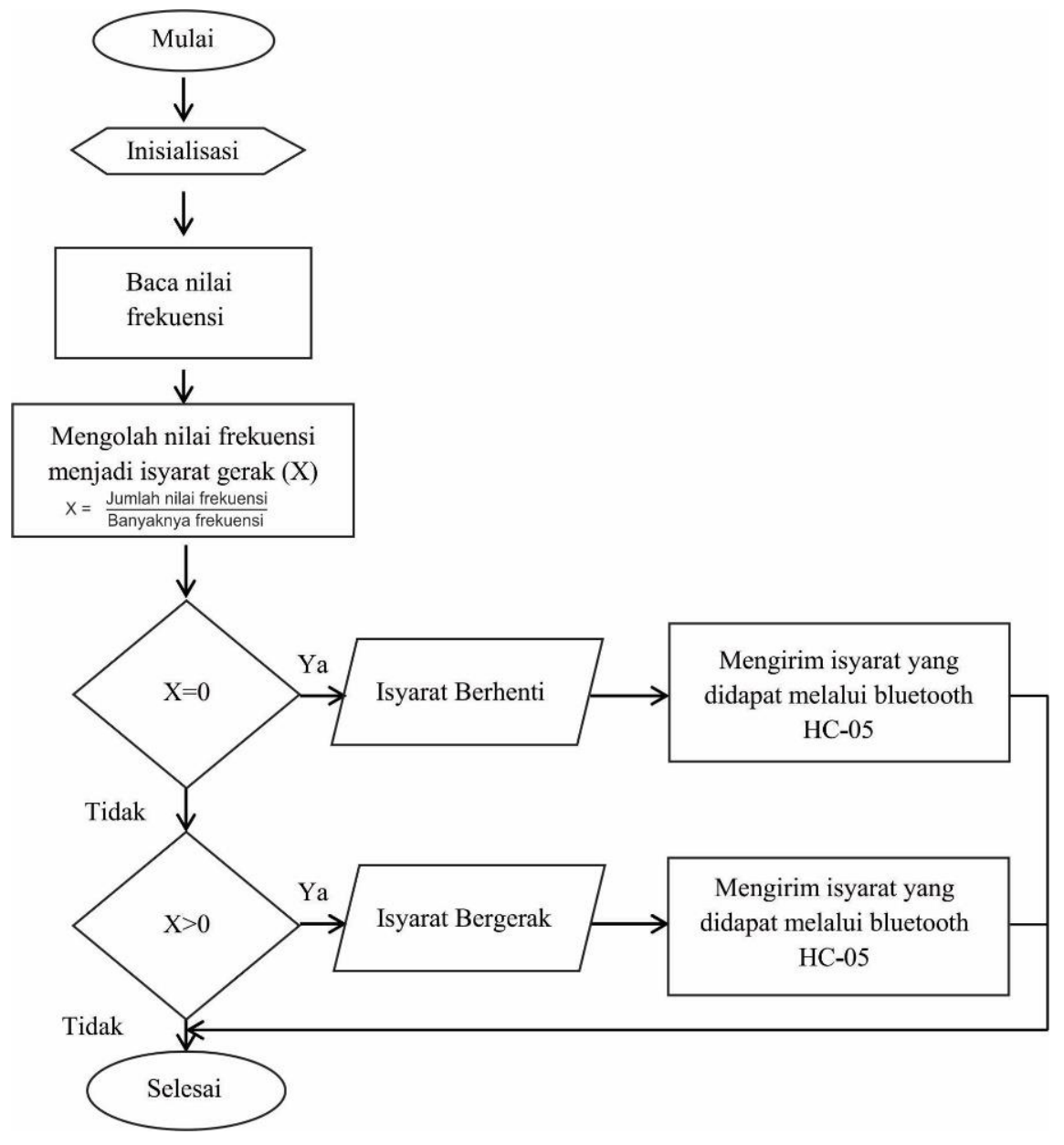

Gambar 3. Diagram Alir Sistem Pengolah Musik

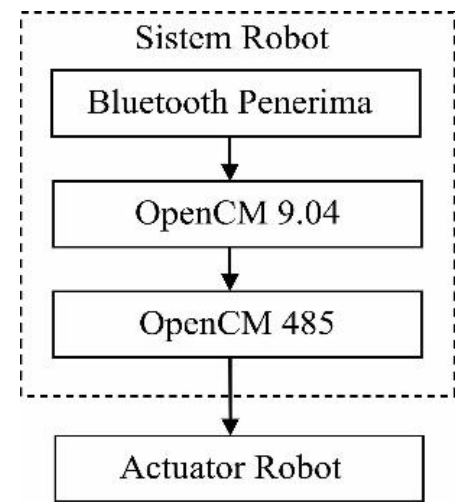

Gambar 4. Diagram Blok Sistem Robot 


\subsubsection{Diagram Alir Sistem Robot}

Robot pada penelitian ini memiliki dua kondisi gerakan yaitu gerakan rawan jatuh dan gerakan aman. Dua kondisi ini dibuat karena mekanik robot yang dirancang dibuat secara modifikasi sehingga tidak seakurat buatan pabrik.

Diagram alir sistem robot dapat dilihat pada Gambar 5. Open CM 9.04 akan menunggu isyarat dari sistem pengolah musik melalui Bluetooth HC-05. Open CM 9.04 akan memproses isyarat gerak, ketika isyarat tersebut untuk bergerak atau bernilai satu, maka sistem akan memanggil gerakan yang telah direkam secara berurutan. Ketika robot sedang menari dan robot mendapat isyarat untuk berhenti, maka gerakan akan dihentikan, tetapi jika isyarat berhenti tersebut diterima saat robot sedang melakukan gerakan rawan jatuh, maka isyarat tersebut akan dihiraukan sementara sampai gerakan rawan tersebut selesai dan robot akan berhenti sampai alunan musik diputar kembali.

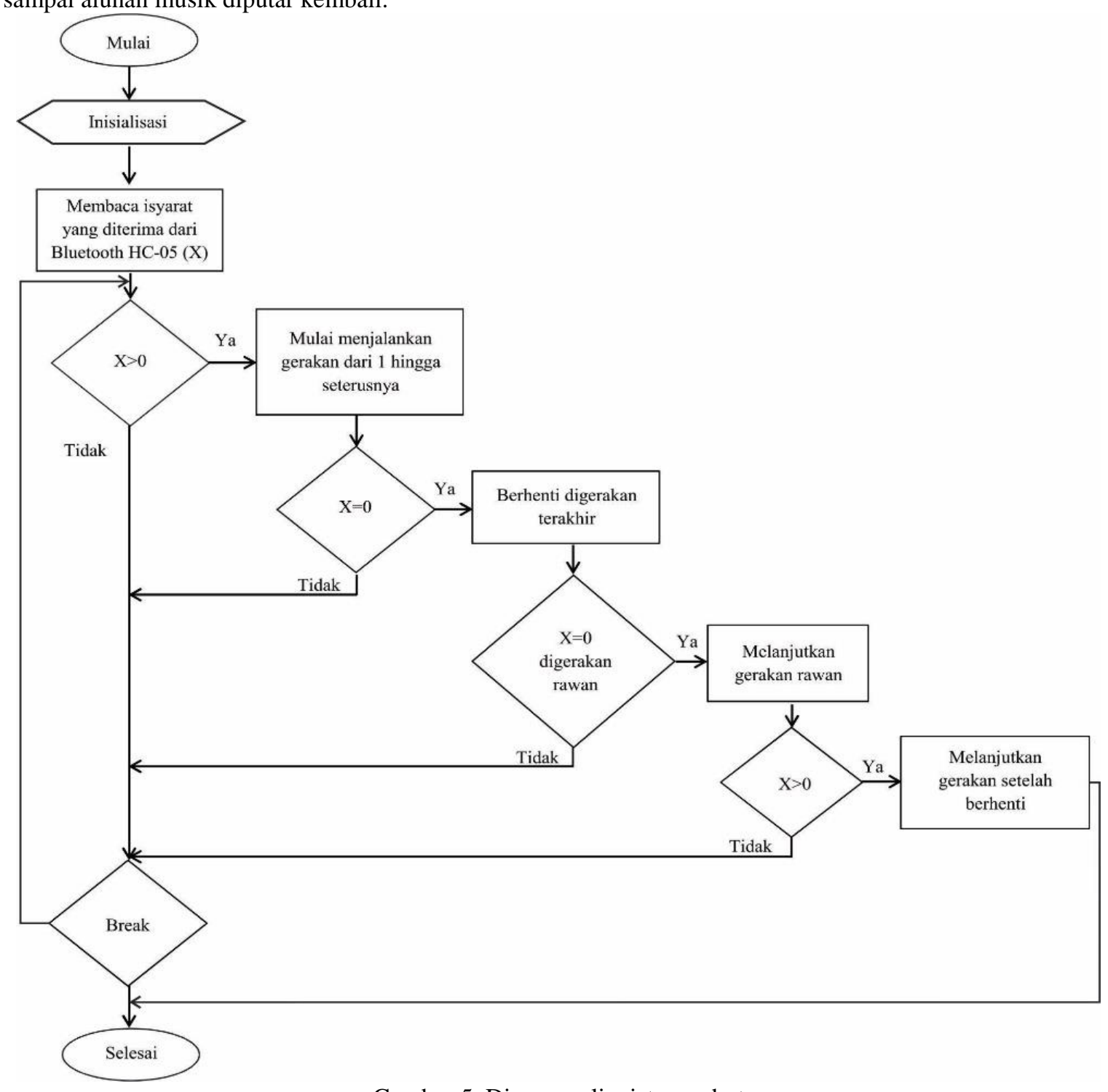

Gambar 5. Diagram alir sistem robot

\subsection{Desain Gerakan Robot}

Gerakan robot dirancang dengan cara robot diposisikan pada pose yang diinginkan dan direkam nilai sudutnya secara berurutan sampai membentuk suatu tarian. Rekaman gerakan yang terbentuk, kemudian nantinya dapat dipanggil sistem robot untuk menggerakkan servo sehingga robot dapat menari. Proses rekam gerakan ini menggunakan fitur serial monitor yang tersedia pada Open CM IDE untuk mengambil nilai sudut servo yang diinginkan.

\subsection{Proses Pengujian}

Rangkaian sistem pengolah musik akan dihubungkan dengan laptop menggunakan jack audio 3.5mm, dari laptop tersebut musik pengiring tari remo diputar menggunakan pemutar musik dan akan diterima oleh IC 
audio analyzer MSGEQ7 dalam bentuk sinyal frekuensi musik dan diteruskan ke kontroler Arduino pro mikro untuk diolah dan dikirimkan ke robot yang sudah disiapkan dalam mode siap di atas arena lomba KRSTI.

Pengujian dilakukan dengan memainkan musik dan membisukan musik secara acak sesuai kondisi ketika kompetisi, pengujian tersebut dilakukan secara berulang ulang untuk melihat hasil atau kinerja sistem apakah bekerja sesuai dengan keinginan atau belum. Pada robot dipasang sebuah LED yang berfungsi sebagai indikator bahwa musik sedang diputar atau berhenti untuk mempermudah dalam pengambilan data. Data hasil pengujian selanjutnya akan dibuat tabel untuk melihat respons dari isyarat gerak yang dikirimkan ke robot dan melihat tingkat akurasi dari respons tersebut.

\section{HASIL DAN PEMBAHASAN}

\subsection{Sistem pengolah musik}

Pengujian frekuensi musik menggunakan FFT pada Matlab untuk mengetahui nilai frekuensi dan amplitudo pada musik tari remo. Hasil FFT menggunakan perangkat lunak Matlab menghasilkan data seperti ditunjukkan pada Gambar 6.

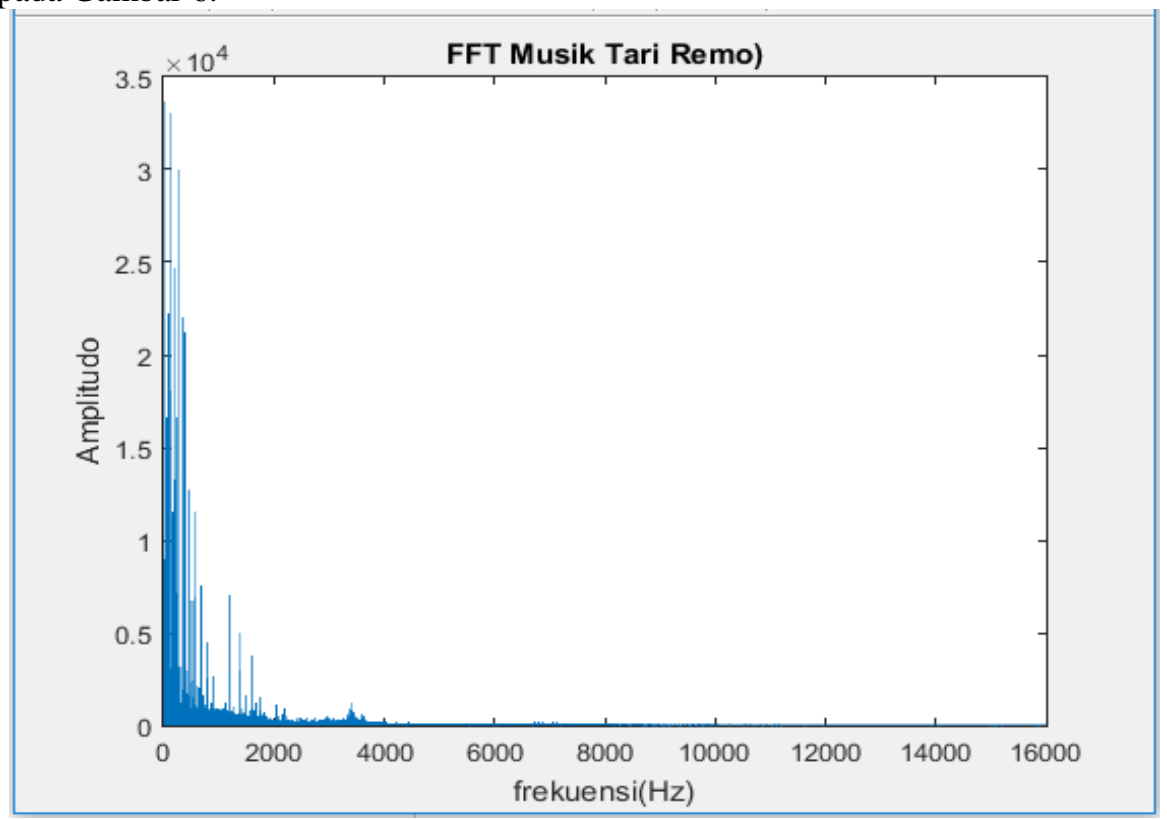

Gambar 6. Hasil komputasi FFT musik Tari Remo

Berdasarkan Gambar 6 dapat diketahui bahwa musik tari remo memiliki nilai amplitudo yang tinggi dan paling sering muncul pada frekuensi $0 \mathrm{~Hz}$ sampai dengan $4000 \mathrm{~Hz}$. Berdasarkan hasil tersebut, peneliti mencocokkannya dengan rentang frekuensi yang dapat dibaca oleh IC MSGEQ7, sehingga dalam sistem pengolah musik frekuensi yang dipakai hanya pada rentang $16 \mathrm{~Hz} ; 63 \mathrm{~Hz} ; 400 \mathrm{~Hz} ; 1 \mathrm{kHz}$; dan $2,5 \mathrm{kHz}$. Untuk lebih jelasnya frekuensi $0-4000 \mathrm{~Hz}$ dapat dilihat pada Gambar 7.

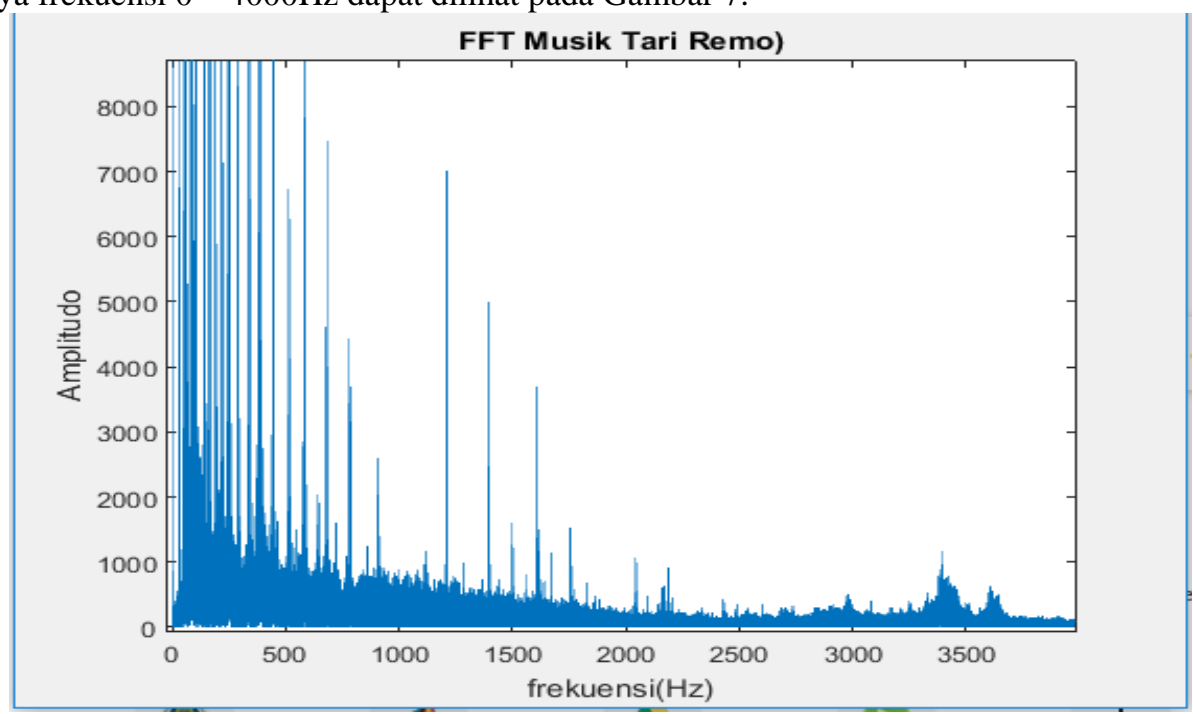

Gambar 7. Pembesaran pada frekuensi $0-4000 \mathrm{~Hz}$ 


\subsection{Pengiriman Isyarat Gerak Robot}

Pengiriman isyarat gerak robot dilakukan menggunakan dua modul Bluetooth HC-05. Dua modul Bluetooth tersebut harus dipasangkan terlebih dahulu dengan mengatur kata sandi, mengatur baudrate ke 38400, dan menautkan alamat kedua modul Bluetooth. Oleh karena itu, koneksi Bluetooth tidak terhubung dengan Bluetooth lain, dan ketika koneksi terputus dapat terhubung kembali secara otomatis.

Hasil pengujian pengiriman data dapat dilihat pada Gambar 8. Pada Gambar 8 terlihat bahwa pengujian dilakukan dengan mengirim data biner 0 dan 1, ketika Bluetooth pengirim mengirimkan data 1, pada serial monitor Bluetooth penerima akan menampilkan data 1 tanpa ada jeda. Pengiriman data menggunakan baudrate 38400 dapat dikatakan bagus karena pengiriman data biner dapat dilakukan dengan cepat dan data tetap akurat.

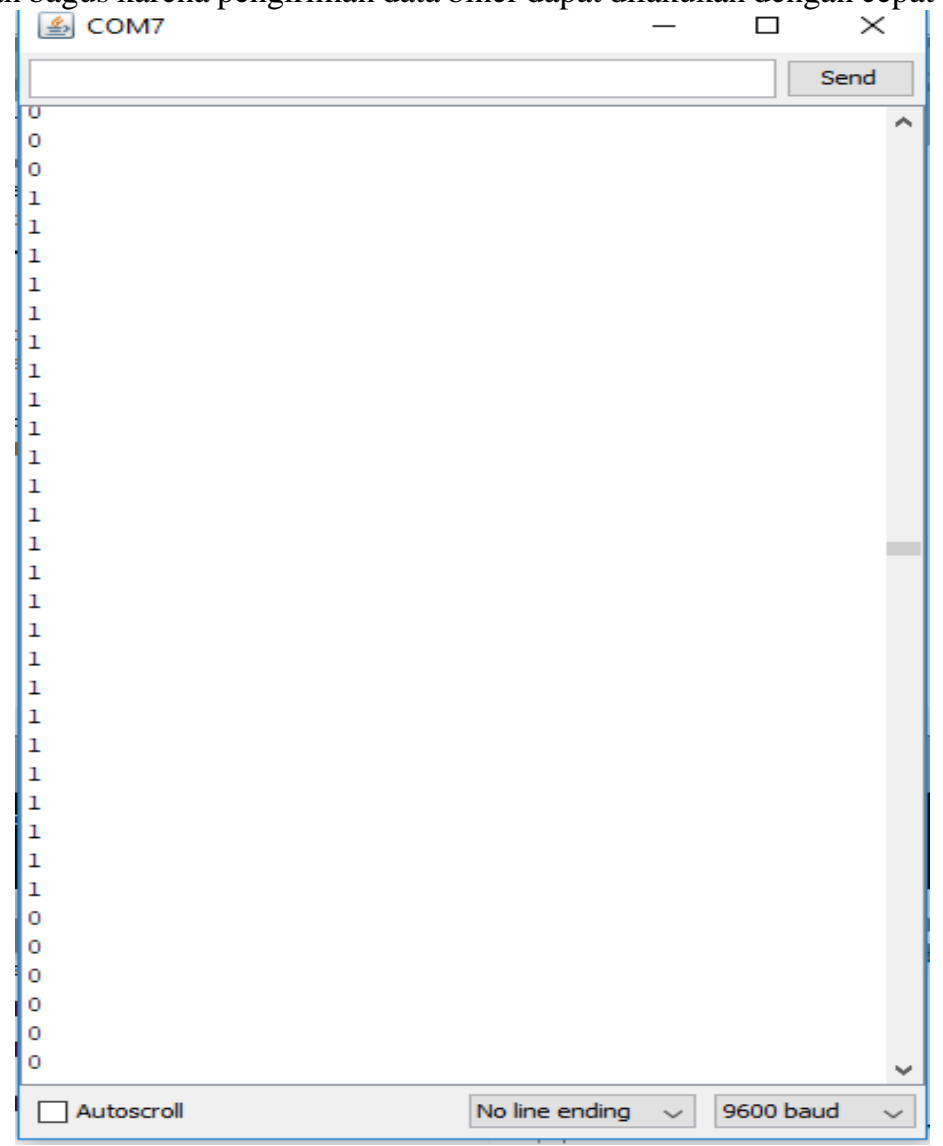

Gambar 8. Hasil pengujian pengiriman isyarat gerak robot

\subsection{Sistem Robot Beserta Analisis}

Pada sistem robot menggunakan dua macam header yaitu dxl_devices.h sebagai header bawaan dari Open CM IDE untuk mengakses servo Dynamixel dan header buatan yaitu LJlibrary.h. Header LJlibrary.h merupakan header yang dibuat sendiri untuk mempermudah dalam mengakses servo, di dalamnya berisi beberapa fungsi seperti berikut:

1. Fungsi ceckingServo berfungsi untuk mengecek jumlah servo yang terpasang pada kontroler.

2. Fungsi startingServo berfungsi sebagai dimulainya servo untuk menggunakan fungsi selanjutnya.

3. Fungsi servoOn dan servoOff berfungsi untuk mengaktifkan dan mematikan servo berdasarkan alamat servo yang diinginkan.

4. Fungsi servoxlWrite (int id, int sudut) berfungsi untuk menulis nilai sudut dari servo xl yang diinginkan.

5. Fungsi servomxWrite (int id, int pos, int sudut) berfungsi untuk menulis nilai sudut dari servo mx yang diinginkan.

6. Fungsi servoxlmxWrite (int id, int pos, int kec) berfungsi untuk menulis kecepatan dari servo xl dan $\mathrm{mx}$ yang diinginkan.

7. Variabel servoxlRead bertipe integer dan digunakan untuk membaca alamat dari servo xl.

8. Variabel servomxRead bertipe integer dan digunakan untuk membaca alamat dari servo $m x$.

9. Fungsi centerposMx berfungsi untuk memosisikan servo mx pada posisi tengah berdasarkan servo yang diinginkan.

10. Fungsi centerposXl berfungsi untuk memosisikan servo xl pada posisi tengah berdasarkan servo yang diinginkan. 
Dalam program utama sistem robot berisi perintah untuk menjalankan robot melalui isyarat gerak yang telah diperoleh dari sistem pengolah musik. Ketika sistem robot dinyalakan, sistem tersebut akan memulai dengan memeriksa apakah button a yang terdapat pada Open CM 485 bernilai 1 atau 0, jika button a sudah bernilai 1 maka robot akan bergerak dalam posisi siap. Dalam keadaan siap system akan memeriksa apakah button b yang terdapat pada Open CM 485 bernilai 1 atau 0. Button b merupakan button yang ditekan jika robot sudah siap untuk melakukan gerakan dalam kata lain button $b$ adalah pengunci untuk memastikan robot tidak berjalan terlebih dahulu.

Ketika button $b$ telah bernilai 1, robot akan menunggu isyarat gerak yang dikirimkan oleh sistem pengolah musik. Ketika sistem robot mendarat isyarat untuk bergerak maka robot akan bergerak dengan gerakan yang sudah dibuat sampai seluruh gerakan selesai atau mendapat isyarat untuk berhenti. Percobaan dilakukan sebanyak 10 kali untuk melihat hasil rata-rata yang diperoleh dari percobaan dan melihat respons gerakan melalui serial monitor pada Open CM IDE. Hasil percobaan dapat dilihat pada Gambar 9 dan Tabel 1.

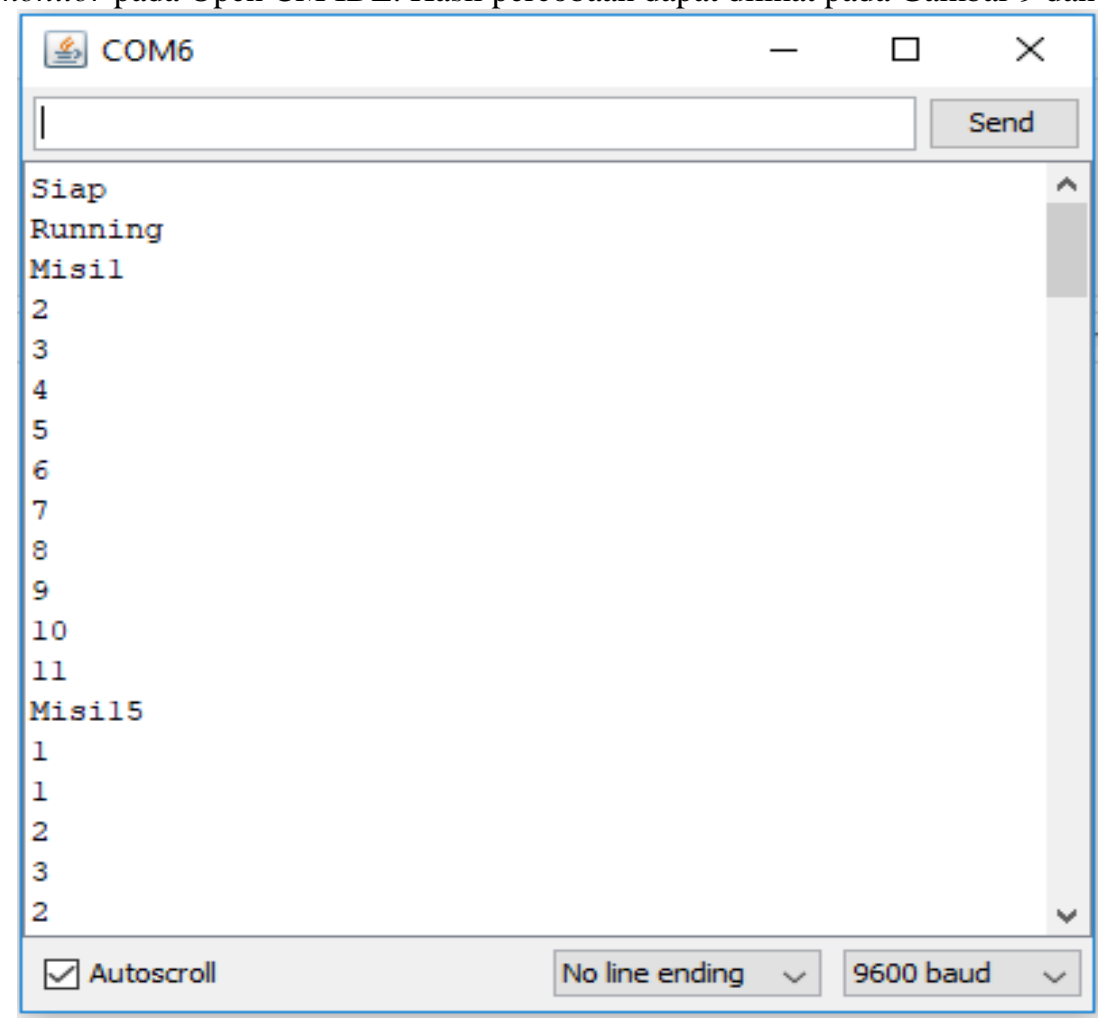

Gambar 9. Hasil Pengujian Robot Melalui Serial Monitor

Tabel 1. Tabel Hasil Pengujian Robot

\begin{tabular}{cccc}
\hline \multirow{2}{*}{ Uji Ke- } & \multicolumn{3}{c}{ Hasil Pengujian Gerakan } \\
\cline { 2 - 4 } & Keberhasilan & Waktu (detik) & Keterangan \\
\hline 1 & Tepat & 0 & Tepat \\
\hline 2 & Terlambat & 0,3 & $\begin{array}{c}\text { Terlambat pada gerakan } \\
\text { Mengangkang } 1\end{array}$ \\
\hline 3 & Tepat & 0,2 & Tepat \\
\hline 4 & Tepat & 0,3 & Tepat \\
\hline 5 & Tepat & 0 & Tepat \\
\hline 6 & Terlambat & 0,5 & $\begin{array}{c}\text { Terlambat pada gerakan } \\
\text { sampan kiri buang }\end{array}$ \\
\hline 7 & Tepat & 0 & Tepat \\
\hline 8 & Terlambat & 0,3 & $\begin{array}{c}\text { Terlambat pada gerakan } \\
\text { Pentang kanan kiri buang } \\
\text { sampur }\end{array}$ \\
\hline 9 & Tepat & 0,3 & Tepat \\
\hline 10 & Tepat & 0 & Tepat \\
\hline
\end{tabular}




\section{KESIMPULAN}

Berdasarkan penelitian hasil pengujian yang telah dilakukan terhadap robot humanoid dengan judul "Sistem Pengolah Musik Sebagai Kontrol Gerak Robot Humanoid", dapat ditarik kesimpulan seperti berikut. Berdasarkan pengujian dapat diketahui frekuensi yang paling sering muncul pada jenis musik tari remo dengan metode FFT (Fast Fourier Transform) sehingga metode ini dapat diterapkan untuk mengetahui karakteristik frekuensi jenis musik tari lain pada perlombaan KRSTI (Kontes Robot Seni Tari Indonesia). Frekuensi yang paling sering muncul pada jenis musik tari remo adalah antara $0 \mathrm{~Hz}$ sampai $4000 \mathrm{~Hz}$. Robot yang dihasilkan dari penelitian ini mampu membedakan kondisi musik, ketika musik sedang diputar robot akan mulai menari dan ketika musik berhenti robot akan berhenti menari. Pengiriman isyarat gerak robot menggunakan Bluetooth HC-05 juga telah mampu mengirimkan isyarat gerak dengan kinerja yang baik, ketika sistem pengolah musik mendapat isyarat untuk menari maka robot akan langsung menerima isyarat untuk menari, begitu juga sebaliknya ketika mendapat isyarat untuk berhenti robot akan langsung menerima isyarat untuk berhenti.

\section{UCAPAN TERIMA KASIH}

Penulis mengucapkan terima kasih yang sebesar-besarnya kepada editor, reviewer, dan semua pihak yang telah mendukung penelitian ini atas segala saran, masukan dan telah membantu dalam proses penerbitan naskah. Selain itu, penulis juga ingin mengucapkan terima kasih kepada BIMAWA UAD yang telah mendukung penelitian dan memberikan bantuan moral dan material.

\section{REFERENSI}

[1] Dikti. Tema dan Aturan Kontes Robot Seni Tari Indonesia (KRSTI) Tahun 2018. 2018;1-18. Online

[2] Bimantara, TEP, "Perancangan sistem pendeteksi suara dari bluetooth receiver dan audio sound system pada kontes robot seni tari indonesia," Universitas Brawijaya, 2018. Online

[3] Putra THA, Syauqy D, Maulana R, "Sistem Pendeteksi Tempo Lagu Untuk Kontes Robot Seni Tari Indonesia (KRSTI) Berdasarkan Frekuensi Dengan Algoritma Beat This," Jurnal Pengembangan Teknologi Informasi dan Ilmu Komputer, vol. 3, 2019. Online

[4] Santoso EA, Sagaf U, Efendi M, Rasyid RF, Gunawan TA, "Klastering Suara Laki-Laki dan Perempuan Menggunakan Algoritma K-Means Berdasarkan Hasil Ekstraksi FFT (Fast Fourier Transform),” Jurnal Edukasi Pendidikan Matematika, vol. 6, 2018. Online

[5] Cotta A, Devidas NT, Ekoskar VKN, "Wireless Communication Using HC-05 Bluetooth Module Interfaced With Arduino," IJSETR, vol. 5, 2016. Online

[6] Zahra R, Thamrin, Jaya P, "Rancang Bangun Robot Humanoid Penari Gending Sriwijaya Menggunakan Modul Easy VR3," VOTEKNIKA, 2017. Online

[7] Kurniasandi AT, Habiburahman M, Iqbal M, "Rancang Bangun Robot Penari Humanoid Untuk KRSTI 2017," Politeknik Manufaktur Negri Bangka Belitung, 2017. Online

[8] Sivy R, Girovsky P, "Master-Slave Control of Dynamixel Actuators," Acta Electrotechnica et Informatica, vol. 14, 2014. DOI: $10.15546 /$ aeei-2014-0018

[9] Rusdiarto, A, "Pengolahan Sinyal Suara Sebagai Pemicu Gerakan Robot Bioloid Cm-530 Menggunakan Arduino," Universitas Sanata Dharma, 2018. Online

[10] Indrajit W, "Rancang Bangun Sistem Motion Capture dan Database Motion untuk Robot Humanoid dengan Perangkat Microsoft Kinect Berbasis ROS,” Universitas Indonesia, 2012. Online

\section{BIOGRAFI PENULIS}

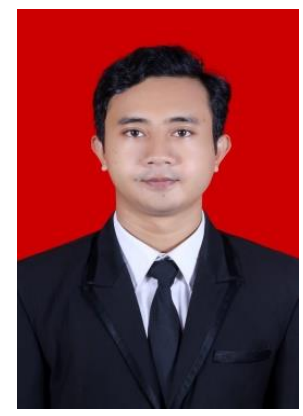

Irmawan Anang Maulana adalah mahasiswa program studi S1 Teknik Elektro di Universitas Ahmad Dahlan angkatan tahun 2015 dan telah menyelesaikan pendidikan tersebut pada tahun 2019. Bidang peminatannya adalah Otomasi Industri. 


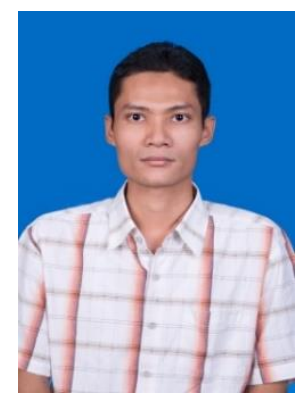

Nuryono Satya Widodo, S.T., M. Eng. adalah dosen di Universitas Ahmad Dahlan. Beliau menyelesaikan pendidikan S2 di Universitas Gadjah Mada (UGM) Indonesia tahun 2010. Konsentrasi Beliau adalah Sistem Isyarat Elektronis. 